\title{
Warming effect on nitrogen fixation in Mediterranean macrophyte sediments
}

\author{
Neus Garcias-Bonet ${ }^{1}$, Raquel Vaquer-Sunyer ${ }^{2}$, Carlos M. Duarte $^{1}$, and Núria Marbà ${ }^{2}$ \\ ${ }^{1}$ King Abdullah University of Science and Technology, Red Sea Research Center, Thuwal 23955-6900, Saudi Arabia \\ ${ }^{2}$ Department of Global Change Research, Institut Mediterrani d'Estudis Avançats, IMEDEA (CSIC-UIB), \\ 07190 Esporles, Mallorca, Spain
}

Correspondence: Neus Garcias-Bonet (neus.garciasbonet@kaust.edu.sa)

Received: 8 August 2018 - Discussion started: 15 August 2018

Revised: 23 November 2018 - Accepted: 17 December 2018 - Published: 17 January 2019

\begin{abstract}
The Mediterranean Sea is warming faster than the global ocean, with important consequences for organisms and biogeochemical cycles. Warming is a major stressor for key marine benthic macrophytes. However, the effect of warming on marine $\mathrm{N}_{2}$ fixation remains unknown, despite the fact that the high productivity of macrophytes in oligotrophic waters is partially sustained by the input of new nitrogen $(\mathrm{N})$ into the system by $\mathrm{N}_{2}$ fixation. Here, we assess the impact of warming on the $\mathrm{N}_{2}$ fixation rates of three key marine macrophytes: Posidonia oceanica, Cymodocea nodosa, and Caulerpa prolifera. We experimentally measured $\mathrm{N}_{2}$ fixation rates in vegetated and bare sediments at temperatures encompassing current summer mean (25 and $27^{\circ} \mathrm{C}$ ), projected summer mean $\left(29\right.$ and $\left.31^{\circ} \mathrm{C}\right)$, and projected summer maximum $\left(33^{\circ} \mathrm{C}\right)$ seawater surface temperatures (SSTs) by the end of the century under a scenario of moderate greenhouse gas emissions. We found that $\mathrm{N}_{2}$ fixation rates in vegetated sediments were 2.8-fold higher than in bare sediments at current summer mean SST, with no differences among macrophytes. Currently, the contribution of $\mathrm{N}_{2}$ fixation to macrophyte productivity could account for up to $7 \%, 13.8 \%$, and $1.8 \%$ of $\mathrm{N}$ requirements for $P$. oceanica, $C$. nodosa, and $C$. prolifera, respectively. We show the temperature dependence of sediment $\mathrm{N}_{2}$ fixation rates. However, the thermal response differed for vegetated sediments, in which rates showed an optimum at $31^{\circ} \mathrm{C}$ followed by a sharp decrease at $33^{\circ} \mathrm{C}$, and bare sediments, in which rates increased along the range of the experimental temperatures. The activation energy and $Q_{10}$ were lower in vegetated than bare sediments, indicating the lower thermal sensitivity of vegetated sediments. The projected warming is expected to increase
\end{abstract}

the contribution of $\mathrm{N}_{2}$ fixation to Mediterranean macrophyte productivity. Therefore, the thermal dependence of $\mathrm{N}_{2}$ fixation might have important consequences for primary production in coastal ecosystems in the context of warming.

\section{Introduction}

Global mean surface temperatures increased $0.85^{\circ} \mathrm{C}$ from 1880 to 2012 and are projected to increase between 1 and $3.5^{\circ} \mathrm{C}$ by the end of the 21 st century relative to preindustrial times (IPCC, 2013). Similarly, heat waves are more frequent since the second half of the 20th century in Europe, Asia, and Australia (IPCC, 2013; Perkins et al., 2012). Oceans store most of the accumulated heat in the biosphere, warming at an average rate of $0.11^{\circ} \mathrm{C}$ per decade at the surface (up to $75 \mathrm{~m}$ of depth) since 1970 (IPCC, 2013), with longer and more frequent marine heat waves over the last century (Oliver et al., 2018). Warming is larger in small and enclosed basins such as the Mediterranean Sea (Vargas-Yáñez et al., 2008), which is warming at $0.61{ }^{\circ} \mathrm{C}$ per decade (Belkin, 2009), with rapid migration of marine isotherms (Burrows et al., 2011) and increased thermal extremes (Diffenbaugh et al., 2007). Specifically, the maximum surface seawater temperature $\left(\mathrm{SST}_{\max }\right)$ in the Balearic Islands, in the western Mediterranean Sea, is projected to increase by $3.4 \pm 1.3^{\circ} \mathrm{C}$ by 2100 under a scenario of moderate greenhouse gas $(\mathrm{GHG})$ emissions (A1B scenario from the IPCC Special Report on Emissions Scenarios, equivalent to the RCP6.0 scenario of the IPCC Fifth Assessment Report) (Jordà et al., 2012), with important consequences for marine organisms and ecosystems. 
Seagrass ecosystems provide important ecosystem services, such as the increase in diversity, the reduction of wave action, the protection of the coast, the increase in water clarity by trapping suspended particles, and climate change mitigation by acting as carbon sinks (Costanza et al., 1997; Duarte, 2017; Fourqurean et al., 2012). In the Mediterranean Sea, the most relevant seagrass species are Posidonia oceanica, an endemic long-living seagrass, and Cymodocea nodosa, commonly found in the eastern Mediterranean Sea and on the northeastern Atlantic coast. Similarly, benthic green macroalgae, such as the autochthonous Mediterranean Caulerpa prolifera, form highly productive ecosystems contributing to the atmospheric $\mathrm{CO}_{2}$ sequestration (Duarte, 2017). However, these coastal vegetated ecosystems are threatened by climate change at the global scale (Duarte et al., 2018) and at the Mediterranean Sea scale (Marbà et al., 2015). In particular, warming increases the mortality rates of P. oceanica (Marba and Duarte, 2010), which is predicted to be functionally extinct by 2049 to 2100 due to warming (Chefaoui et al., 2018; Jordà et al., 2012). Mesocosm experiments showed that $C$. nodosa is more resistant to warming than P. oceanica (Olsen et al., 2012), concurrent with thermal niche models (Chefaoui et al., 2016, 2018); however, a loss of $46.5 \%$ in $C$. nodosa extension is predicted by 2100 under the worst-case warming scenario (Chefaoui et al., 2018). Although C. prolifera thrives well in warm waters, its photosynthesis is inhibited at temperatures above $30^{\circ} \mathrm{C}$ (Lloret et al., 2008; Vaquer-Sunyer and Duarte, 2013), compromising its survival at temperatures above this threshold.

Warming also affects metabolic processes driving biogeochemical cycles in coastal benthic ecosystems. Warming enhances sediment sulfate reduction rates (Robador et al., 2016), leading to an increase in sulfide accumulation in coastal bare sediments (Sanz-Lázaro et al., 2011) and seagrass-colonized sediments (Koch et al., 2007). In the Mediterranean Sea, heat waves and warming trigger sulfide intrusion in P. oceanica shoots (García et al., 2013), which has toxic effects on plant meristems (Garcias-Bonet et al., 2008) and increases shoot mortality (Calleja et al., 2007). Sanz-Lázaro et al. (2011) found that warming enhances sediment oxygen uptake and $\mathrm{CO}_{2}$ emissions in coastal sediments, boosted by the addition of labile organic matter, in a mesocosm experiment. Similarly, warming together with eutrophication have been identified as main drivers of hypoxia in a Mediterranean macroalgae Caulerpa prolifera meadow (Vaquer-Sunyer et al., 2012). However, studies on the effect of warming on atmospheric nitrogen fixation in coastal marine ecosystems are lacking.

Nitrogen $\left(\mathrm{N}_{2}\right)$ fixation plays a fundamental role in balancing nutrient budgets at the basin scale in the Mediterranean Sea, with most of this $\mathrm{N}_{2}$ fixation associated with $P$. oceanica seagrass meadows (Béthoux and Copin-Montégut, 1986). Indeed, endophytic nitrogen-fixing bacteria have been detected in roots of P. oceanica (Garcias-Bonet et al., 2012, 2016) and $\mathrm{N}_{2}$ fixation has been reported in leaves and roots of $P$. ocean- ica (Agawin et al., 2016; Lehnen et al., 2016) and in situ incubations (Agawin et al., 2017). Therefore, the high productivity of $P$. oceanica in the oligotrophic Mediterranean waters is partially supported by $\mathrm{N}_{2}$ fixation. However, the magnitude of $\mathrm{N}_{2}$ fixation rates in the rhizosphere of $P$. oceanica is still unknown, as is $\mathrm{N}_{2}$ fixation associated with other key macrophytes commonly found in the Mediterranean Sea, such as $C$. nodosa and $C$. prolifera. In addition, whether warming will affect $\mathrm{N}_{2}$ fixation rates is still unknown.

Here, we test the hypothesis that $\mathrm{N}_{2}$ fixation rates in coastal ecosystems is temperature dependent and will increase with the forecasted warming. We do so by experimentally assessing the response of $\mathrm{N}_{2}$ fixation rates to warming in coastal Mediterranean vegetated ecosystems. We focus specifically on the key macrophyte species most commonly found in the Mediterranean Sea: two seagrass species (P. oceanica, $C$. nodosa) and one green macroalgae species (C. prolifera). We experimentally measured $\mathrm{N}_{2}$ fixation rates in vegetated and bare sediments at temperatures encompassing the current summer mean SST range $\left(25\right.$ and $\left.27^{\circ} \mathrm{C}\right)$, the projected summer mean SST range $\left(29\right.$ and $31^{\circ} \mathrm{C}$ ), and projected summer $\mathrm{SST}_{\max }\left(33^{\circ} \mathrm{C}\right)$ by the end of the century under a scenario of moderate GHG emissions to assess (i) differences between vegetated and bare sediments, (ii) differences among macrophyte species, and (iii) the thermal dependence of sediment $\mathrm{N}_{2}$ fixation rates.

\section{Materials and methods}

\subsection{Study site}

The study was conducted with benthic communities sampled in Pollença Bay (Mallorca, Spain), a bay located in the western Mediterranean Sea ( $39^{\circ} 53.792^{\prime}$ N, $3^{\circ} 5.523^{\prime}$ E). The study site was selected based on the coexistence of the three most commonly found macrophyte species in the region, including two seagrasses (Posidonia oceanica and Cymodocea nodosa) and one green macroalgae (Caulerpa prolifera). The three macrophytes grow close to each other in monospecific patches at $5 \mathrm{~m}$ of depth. Mean $( \pm \mathrm{SE})$ shoot density estimates

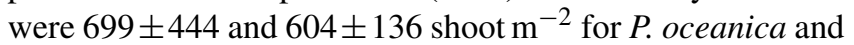
C. nodosa, respectively (Marbà and Vaquer-Sunyer, unpublished). The study was conducted in mid-June 2017 when in situ daily mean $( \pm \mathrm{SE}) \mathrm{SST}$ was $26.4 \pm 0.08^{\circ} \mathrm{C}$.

We sampled sediment colonized by these three macrophytes and the adjacent bare sediment using sediment cores (50 $\mathrm{cm}$ in length and $4.5 \mathrm{~cm}$ in diameter). We collected 16 sediment cores for each type of sediment. The vegetated sediment cores were collected from the center of the macrophyte patches between shoots or blades, collecting belowground plant material but avoiding the collection of aboveground biomass. The bare sediment cores were collected about $5 \mathrm{~m}$ away from the edge of the vegetated patches. We collected the sediment samples by pushing the cores down into the 
sediment with the help of a rubber hammer and carefully extracting at least $15 \mathrm{~cm}$ of undisturbed top sediment. The cores were transported immediately to the laboratory. We measured seawater salinity using a calibrated conductivity meter (ProfiLine Cond 3310; WTW ${ }^{\circledR}$, USA) and summer SST was monitored and recorded in situ every $2 \mathrm{~h}$ from 2012 to 2017 using a Hobo logger (Onset Computer Corporation ${ }^{\circledR}$, MA, USA). Full summer SST records are available for 2012, 2013, 2106, and 2017. No data are available for 2015, and only partial temporal coverage is available for 2014 (Fig. S1 in the Supplement). The summer mean $( \pm$ SE) SST varied from $26.29 \pm 0.05^{\circ} \mathrm{C}$ in 2013 to $27.03 \pm 0.04^{\circ} \mathrm{C}$ in 2017 , with an average summer mean SST of $26.54 \pm 0.17^{\circ} \mathrm{C}$ from 2012 to 2017. Average summer minimum and maximum SST were 22.92 and $29.08^{\circ} \mathrm{C}$, respectively. The highest maximum SST was $29.67^{\circ} \mathrm{C}$ and was registered in August 2017 (Table S1 in the Supplement).

\subsection{Nitrogen fixation rates}

We measured sediment $\mathrm{N}_{2}$ fixation rates in an acetylene reduction assay (Capone and Taylor, 1980) in P. oceanica, $C$. nodosa, and $C$. prolifera vegetated sediments and the adjacent bare sediment at five incubation temperatures: 25, 27, 29,31 , and $33^{\circ} \mathrm{C}$. The 25 and $27^{\circ} \mathrm{C}$ temperature treatments represent the current summer mean SST, covering the in situ recorded average summer mean SST of $26.54 \pm 0.2^{\circ} \mathrm{C}(25 \%$ percentile $=25.81^{\circ} \mathrm{C}$ and $75 \%$ percentile $=27.61^{\circ} \mathrm{C}$ ) from 2012 to 2017 . The 29 and $31^{\circ} \mathrm{C}$ temperature treatments represent the range of the projected summer mean SST by the end of the century under a scenario of moderate GHG emissions equivalent to RCP6.0 by applying the projected mean SST increase of $2.8 \pm 1.1^{\circ} \mathrm{C}$ in the region (Jordà et al., 2012) over the summer mean SST registered in $2017\left(27.03^{\circ} \mathrm{C}\right)$. The $33^{\circ} \mathrm{C}$ temperature treatment represents the projected summer $\mathrm{SST}_{\max }$ by the end of the century under a scenario of moderate GHG emissions equivalent to RCP6.0 by applying the projected $\mathrm{SST}_{\max }$ increase of $3.4 \pm 1.3^{\circ} \mathrm{C}$ (Jordà et al., 2012) over the summer $\mathrm{SST}_{\max }$ of $29.67^{\circ} \mathrm{C}$ already recorded in 2017. The sediment incubations were run in five water baths (i.e., one per temperature treatment) equipped with thermometers and heaters located in a stable temperature room. The target temperature for each water bath was maintained using an IKS-AQUASTAR system, which controlled and recorded the temperature every $10 \mathrm{~min}$. During the incubations, the temperature oscillation around the target temperatures ranged from 0.3 to $0.7^{\circ} \mathrm{C}$, and the temperature accuracy was $\pm 0.05^{\circ} \mathrm{C}$ on average (Table S2).

Once in the laboratory, the sediment from the cores was extruded carefully using a plunger, and the first $10 \mathrm{~cm}$ of sediment below the surface was collected; the rest of the sediment in the core was discarded. For each replicate, $80 \mathrm{~mL}$ of sediment together with the belowground biomass present was placed in a $500 \mathrm{~mL}$ glass bottle. No aboveground biomass was included in the incubation glasses. Then, we added
$200 \mathrm{~mL}$ of autoclaved seawater and the bottles were closed with a lid fitted with a gas-tight valve. Finally, we added $20 \mathrm{~mL}$ of acetylene-saturated seawater through the gas-tight valve of each bottle in order to achieve a final acetylene concentration of $4 \mathrm{mM}$. The acetylene-saturated seawater was prepared according to Wilson et al. (2012). We ran the sediment incubations in triplicate for each type of sediment and each temperature treatment under dark conditions. The incubations lasted $24 \mathrm{~h}$, starting after the addition of acetylenesaturated seawater. We sampled the headspace five times: at the start of the experiment and at 12,17,20, and $24 \mathrm{~h}$ since the onset of the experiment. Specifically, we withdrew $3 \mathrm{~mL}$ of air from the headspace with a gas-tight syringe. The headspace air sample was immediately injected into a $3 \mathrm{~mL}$ vacuum vial for further analysis of ethylene concentration on a gas chromatographer equipped with a flame ionization detector (FID-GC; Agilent 5890) using a PoraPLOT U GC column $(25 \mathrm{~m} \times 0.53 \mathrm{~mm} \times 20 \mu \mathrm{m}$; Agilent Technologies, USA). We built a calibration curve using three ethylene standards of known concentration $(1.02,10.13$, and $99.7 \mathrm{ppm}$ ) and helium as a balance gas, supplied by Carburos Metálicos S.A. (Palma de Mallorca, Spain). We estimated the concentration of dissolved ethylene from the ethylene concentration in the equilibrated air as described previously (Wilson et al., 2012) and applied the solubility coefficient of ethylene according to Breitbarth et al. (2004) as a function of temperature and salinity.

We ran negative controls consisting of sediment without the addition of acetylene-saturated seawater in order to confirm that ethylene was not naturally produced by our samples and autoclaved seawater used in the preparation of the incubations with the addition of acetylene-saturated seawater in order to confirm that ethylene was not produced in the seawater. No ethylene was produced in any of the negative controls. The ethylene production rates were converted into $\mathrm{N}_{2}$ fixation rates by applying the common ratio of $3 \mathrm{~mol}$ of acetylene to $1 \mathrm{~mol}$ of $\mathrm{N}_{2}$ (Welsh, 2000).

At the end of the incubation, we dried the sediment samples at $60^{\circ} \mathrm{C}$ and recorded the dry weight for further calculations. Moreover, we calculated the sediment organic matter (OM) content of each replicate sediment sample by loss on ignition (Dean Jr., 1974). The sediment $\mathrm{N}_{2}$ fixation rates were first calculated by sediment dry weight and then standardized to surface area integrated over $10 \mathrm{~cm}$ of sediment depth by taking into account the sediment bulk density.

\subsection{Statistical analysis}

Differences in sediment OM content and bulk density among $P$. oceanica, $C$. nodosa, and $C$. prolifera vegetated sediments and bare sediment were tested with the nonparametric Kruskal-Wallis test. Differences in sediment $\mathrm{N}_{2}$ fixation rates among the four types of sediment (P. oceanica, C. nodosa, and $C$. prolifera vegetated sediments and bare sediment) were tested by Friedman test matching by temperature 
treatment. Then, we tested the effect of temperature (as a categorical explanatory variable with three levels: current summer mean SST range $\left(25\right.$ and $\left.27^{\circ} \mathrm{C}\right)$, projected summer mean SST range $\left(29\right.$ and $31^{\circ} \mathrm{C}$ ), and projected summer $\mathrm{SST}_{\max }$ $\left(33^{\circ} \mathrm{C}\right)$ ) and type of sediment (as a categorical explanatory variable with two levels: vegetated and bare sediments) on sediment $\mathrm{N}_{2}$ fixation rates (our response variable) after a $\log$ transformation to meet normality requirements by a full factorial two-way ANOVA. Finally, differences in sediment $\mathrm{N}_{2}$ fixation rates between vegetated and bare sediments were tested by a nonparametric Mann-Whitney $U$ test at three different temperature ranges: current summer mean SST range (25 and $27^{\circ} \mathrm{C}$ ), projected summer mean SST range (29 and $\left.31^{\circ} \mathrm{C}\right)$, and projected summer $\mathrm{SST}_{\max }\left(33^{\circ} \mathrm{C}\right)$. Moreover, we tested the thermal dependence of sediment $\mathrm{N}_{2}$ fixation rates in vegetated and bare sediments by fitting the Arrhenius function to estimate the activation energy $(E a)$, derived from the linear regression between the natural logarithm of $\mathrm{N}_{2}$ fixation rates and the inverse of the temperature multiplied by the Boltzmann constant (Dell et al., 2011), and $Q_{10}$, the relative rate of increase in $\mathrm{N}_{2}$ fixation expected for a $10^{\circ} \mathrm{C}$ temperature increase (Raven and Geider, 1988). The $Q_{10}$ was calculated using the following equation (Raven and Geider, 1988):

$Q_{10}=e^{\left(\frac{10 E a}{R T^{2}}\right)}$,

where $R$ is the gas constant $\left(8.314472 \mathrm{~mol}^{-1} \mathrm{~K}^{-1}\right), T$ is the mean absolute temperature across the range over which $Q_{10}$ was measured $(\mathrm{K})$, and $E a$ is the activation energy $\left(\mathrm{J} \mathrm{mol}^{-1}\right)$. The activation energy and $Q_{10}$ of $\mathrm{N}_{2}$ fixation in vegetated sediments were calculated using the increasing rates measured at four temperature treatments $\left(25,27,29\right.$, and $\left.31^{\circ} \mathrm{C}\right)$, while the declining rates measured at $33^{\circ} \mathrm{C}$ were not included. The full range of temperature treatments was used for bare sediments since no decline was detected. All statistical analyses were performed using JMP (SAS Institute Inc., USA) and PRISM (GraphPad Software Inc., USA) statistical software.

\section{Results}

Sediment OM content was significantly different in the sediments colonized by different macrophyte species $\left(\chi_{3,56}^{2}=\right.$ 50.33, $p<0.0001)$. Posidonia oceanica sediments had the highest OM content $(13.34 \pm 0.56 \%)$, whereas bare sediments had the lowest OM content $(0.44 \pm 0.50 \%$, Table 1$)$. Sediment bulk density differed among sediment types $\left(\chi_{3,56}^{2}=46.02, p<0.0001\right.$; Table 1$)$.

Average $\mathrm{N}_{2}$ fixation rates in bare sediments were $0.06 \pm$ $0.01 \mathrm{nmol} \mathrm{N} \mathrm{g} \mathrm{DW}^{-1} \mathrm{~h}^{-1}$ (range from 0.01 to 0.09), while average $\mathrm{N}_{2}$ fixation rates in vegetated sediments were 3-fold greater at $0.19 \pm 0.03 \mathrm{nmol} \mathrm{Ng} \mathrm{DW}^{-1} \mathrm{~h}^{-1}$ (range from 0.05 to 0.9 ), pooling all temperature treatments together. Within the vegetated sediments, the maximum mean
$\mathrm{N}_{2}$ fixation rate was detected in $C$. prolifera $(0.22 \pm$ $\left.0.05 \mathrm{nmol} \mathrm{N} \mathrm{g} \mathrm{DW}^{-1} \mathrm{~h}^{-1}\right)$, whereas the minimum mean $\mathrm{N}_{2}$ fixation rate was measured in $C$. nodosa $(0.15 \pm 0.04 \mathrm{nmol}$ $\mathrm{NgDW}^{-1} \mathrm{~h}^{-1}$ ). The mean $\mathrm{N}_{2}$ fixation rate in $P$. oceanica was $0.21 \pm 0.06 \mathrm{nmol} \mathrm{N} \mathrm{g} \mathrm{DW}^{-1} \mathrm{~h}^{-1}$. Nitrogen fixation rates differed among the four different sediment types (i.e., bare, P. oceanica, C. nodosa, and C. prolifera sediments) $\left(\chi_{3,56}^{2}=\right.$ $10.68, p=0.005)$ when expressed by sediment dry weight. However, once the rates were converted into aerial basis, these differences were no longer significant $\left(\chi_{3,56}^{2}=6.12\right.$, $p>0.05$ ) due to high variability in sediment bulk densities. Sediment $\mathrm{N}_{2}$ fixation rates were independent of OM content (linear regression, $\mathrm{d} f N=1, \mathrm{~d} f D=58$, Pearson's $r=0.19$, $p>0.05$ ).

Nitrogen fixation rates in aerial basis were significantly higher in vegetated sediments compared to bare ones $(U=$ $154, p<0.002)$ when pooling all temperature treatments together, with sediments colonized by macrophytes supporting, on average, twice the nitrogen fixation rate as bare sediments (mean $\pm \mathrm{SE}=3.86 \pm 0.53$ and $1.77 \pm 0.20 \mathrm{mg} \mathrm{N} \mathrm{m}^{-2} \mathrm{~d}^{-1}$, respectively), considering all temperature treatments. Temperature and type of sediment (vegetated and bare sediments) had a significant effect on $\mathrm{N}_{2}$ fixation rates (twoway ANOVA; sediment type $F_{1,59}=10.40, p<0.01$; temperature $F_{2,59}=4.89, p<0.05$ ), with no significant interaction between them. Specifically, at the current summer SST range $\left(25-27^{\circ} \mathrm{C}\right), \mathrm{N}_{2}$ fixation rates in vegetated sediments $\left(3.15 \pm 0.48 \mathrm{mg} \mathrm{N} \mathrm{m}^{-2} \mathrm{~d}^{-1}\right)$ were significantly higher $(U=$ $13, p<0.01)$ than those in bare sediments $(1.14 \pm 0.3 \mathrm{mg}$ $\mathrm{N} \mathrm{m}^{-2} \mathrm{~d}^{-1}$ ) (Fig. 1a). Similarly, at the projected summer mean SST range $\left(29-31^{\circ} \mathrm{C}\right), \mathrm{N}_{2}$ fixation rates in vegetated sediments $\left(5.25 \pm 1.17 \mathrm{mg} \mathrm{N} \mathrm{m}^{-2} \mathrm{~d}^{-1}\right)$ were significantly higher $(U=23, p<0.05)$ than the rates measured in bare sediments $\left(2.18 \pm 0.2 \mathrm{mg} \mathrm{N} \mathrm{m}^{-2} \mathrm{~d}^{-1}\right)$ (Fig. 1b). However, $\mathrm{N}_{2}$ fixation rates did not differ between vegetated and bare sediments at projected summer $\mathrm{SST}_{\max }\left(33^{\circ} \mathrm{C}\right)$, with $\mathrm{N}_{2}$ fixation rates of $2.49 \pm 0.248$ and $2.21 \pm 0.15 \mathrm{mg} \mathrm{N} \mathrm{m}^{-2} \mathrm{~d}^{-1}$, respectively (Fig. 1c).

In vegetated sediments, $\mathrm{N}_{2}$ fixation rates increased linearly with temperature up to $31^{\circ} \mathrm{C}\left(\mathrm{N}_{2}\right.$ fixation (nmol $\left.\mathrm{Ng} \mathrm{DW}^{-1} \mathrm{~h}^{-1}\right)=-0.63+0.03 \times$ temperature, $R^{2}=0.11$, $p<0.05$ ), with a marked decrease from $0.32 \pm 0.09 \mathrm{nmol}$ $\mathrm{Ng} \mathrm{DW}^{-1} \mathrm{~h}^{-1}$ at $31^{\circ} \mathrm{C}$ to $0.11 \pm 0.01 \mathrm{nmol} \mathrm{Ng} \mathrm{DW}^{-1} \mathrm{~h}^{-1}$ at $33^{\circ} \mathrm{C}$ (Fig. 2). Nitrogen fixation rates in bare sediments increased linearly with temperature up to $33^{\circ} \mathrm{C}\left(\mathrm{N}_{2}\right.$ fixation $\left(\mathrm{nmol} \mathrm{N} \mathrm{g} \mathrm{DW}^{-1} \mathrm{~h}^{-1}\right)=-0.11+0.01 \times$ temperature, $R^{2}=0.51, p<0.005$, Fig. 2). The associated activation energies were $0.91 \pm 0.39$ and $1.25 \pm 0.39 \mathrm{eV}$ for vegetated and bare sediments, respectively (Fig. 3). The associated $Q_{10}$ values were $3.84 \pm 2.22$ and $6.41 \pm 2.97$ for vegetated and bare sediments, respectively. 
Table 1. Organic matter content and bulk density in sediments colonized by different macrophyte species and bare sediment in Pollença Bay (Mallorca) in June 2017. Mean values ( \pm SEM), ranges (minimum-maximum values), and the sample size $(N)$ are shown.

\begin{tabular}{lrrrr}
\hline & P. oceanica sediment & C. nodosa sediment & C. prolifera sediment & Bare sediment \\
\hline Sediment organic & $12.58 \pm 0.95$ & $6.14 \pm 0.39$ & $0.74 \pm 0.12$ & $0.44 \pm 0.08$ \\
matter content (\%) & $(8.17-20.63)$ & $(4.49-10.22)$ & $(0.04-1.31)$ & $(0.02-1.41)$ \\
& $N=15$ & $N=15$ & $N=15$ & $N=15$ \\
\hline Sediment bulk density & $0.54 \pm 0.03$ & $1.01 \pm 0.03$ & $0.46 \pm 0.02$ & $0.96 \pm 0.02$ \\
$\left(\mathrm{~g} \mathrm{DW} \mathrm{sed} \mathrm{cm}^{-3}\right)$ & $(0.29-0.69)$ & $(0.74-1.24)$ & $(0.32-0.56)$ & $(0.84-1.09)$ \\
& $N=15$ & $N=15$ & $N=15$ & $N=15$ \\
\hline
\end{tabular}
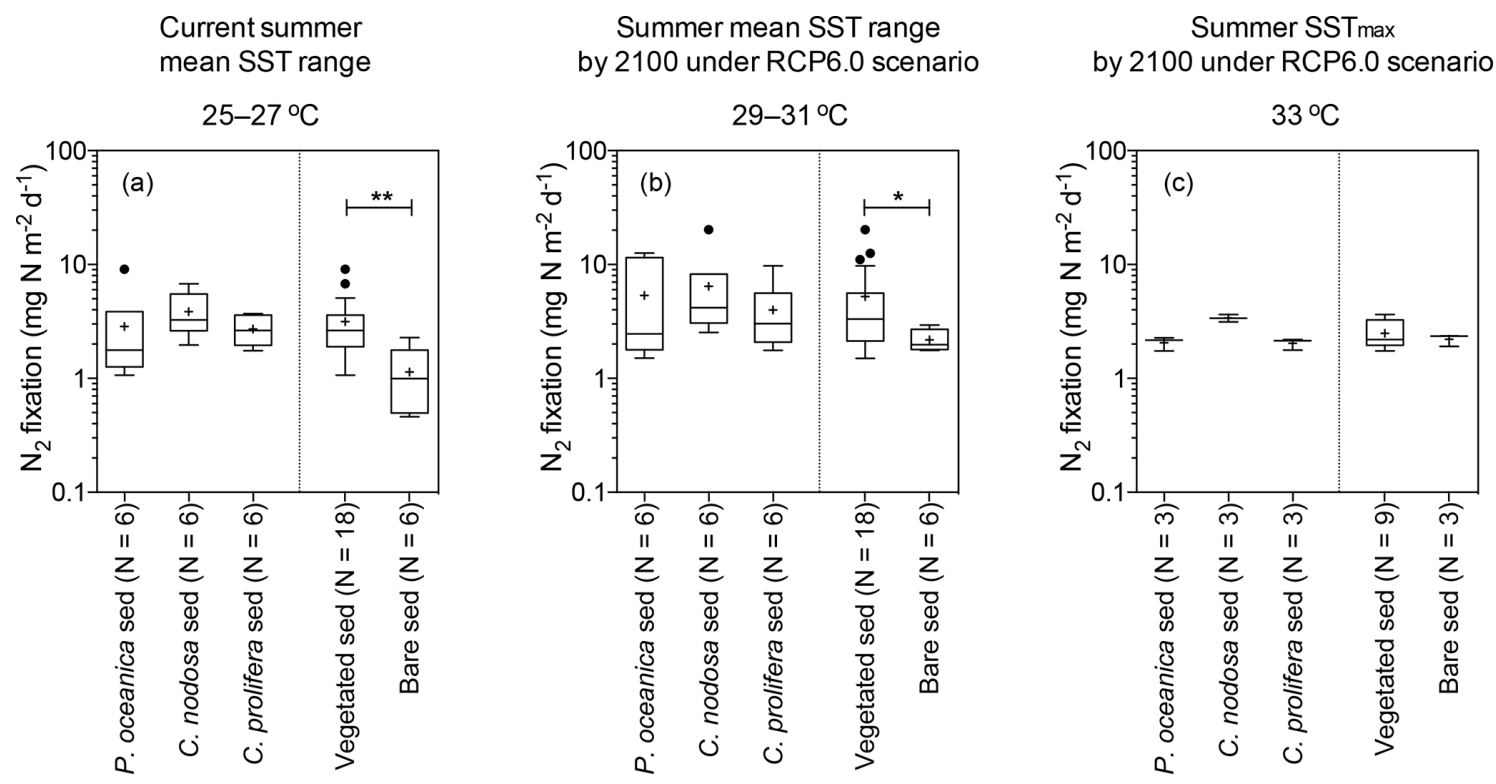

Figure 1. Box plot of the $\mathrm{N}_{2}$ fixation rates (expressed by area) of sediments colonized by different macrophytes (as well as grouping all vegetated sediments together) and bare sediment measured at the current summer SST range $\left(25-27^{\circ} \mathrm{C}\right.$, a), the projected summer mean SST range by 2100 under RCP6.0 scenario $\left(29-31^{\circ} \mathrm{C}\right.$, b), and the projected summer $\mathrm{SST}_{\max }$ by 2100 under RCP6.0 $\left(33^{\circ} \mathrm{C}\right.$, c). Boxes extend from the 25 th to 75 th percentiles, whiskers are calculated using the interquartile distance (IQR) according to the Tukey method, lines inside boxes represent the median, "+" represents the mean, and dots represent individual values greater than the 75th percentile plus $1.5 \mathrm{X}$ IQR. Statistically significant differences are indicated by asterisks; ${ }^{*}$ indicates $p<0.05$ and ${ }^{* *}$ indicates $p<0.01$. The sample size $(N)$ is also indicated.

\section{Discussion}

The overall average $\mathrm{N}_{2}$ fixation rate found in Mediterranean vegetated sediments at current summer mean SST $\left(3.15 \pm 0.48 \mathrm{mg} \mathrm{N} \mathrm{m}^{-2} \mathrm{~d}^{-1}\right)$ is within the range of rates reported for sediments colonized by temperate seagrass species (from 1.2 to $6.5 \mathrm{mg} \mathrm{N} \mathrm{m}^{-2} \mathrm{~d}^{-1}$ in Zostera marina sediments in the North Sea (McGlathery et al., 1998) and on the northwest Atlantic coast (Capone, 1982) and from 0.1 to $7.3 \mathrm{mg} \mathrm{N} \mathrm{m}^{-2} \mathrm{~d}^{-1}$ in Zostera noltii on the northeast Atlantic coast; Welsh et al., 1996). However, $\mathrm{N}_{2}$ fixation rates are lower than the rates reported for tropical and subtropical seagrass species (see references in Welsh, 2000). The overall $\mathrm{N}_{2}$ fixation rates in vegetated sediments are higher than in bare sediments, consistent with the long-recognized role of marine plants in enhancing $\mathrm{N}_{2}$ fixation rates (Capone, 1988). Specifically, the vegetated sediments supported 3- to 4-fold higher $\mathrm{N}_{2}$ fixation rates than bare sediments at the current summer mean SST range when expressed by area and by sediment dry weight, respectively.

The $\mathrm{N}_{2}$ fixation rates we measured in $P$. oceanica sediments at current summer mean SST $(2.86 \pm 1.26 \mathrm{mg}$ $\mathrm{N} \mathrm{m}^{-2} \mathrm{~d}^{-1}$ ) are higher than the rates reported in summer at similar seawater temperature by Agawin et al. (2017) using benthic bell-jar chambers containing $P$. oceanica shoots and the underlying sediment (ranging from 0.06 to $1.51 \mathrm{mg} \mathrm{N} \mathrm{m}^{-2} \mathrm{~d}^{-1}$ ). However, the different methodological approaches make comparisons difficult: while sediment slur- 


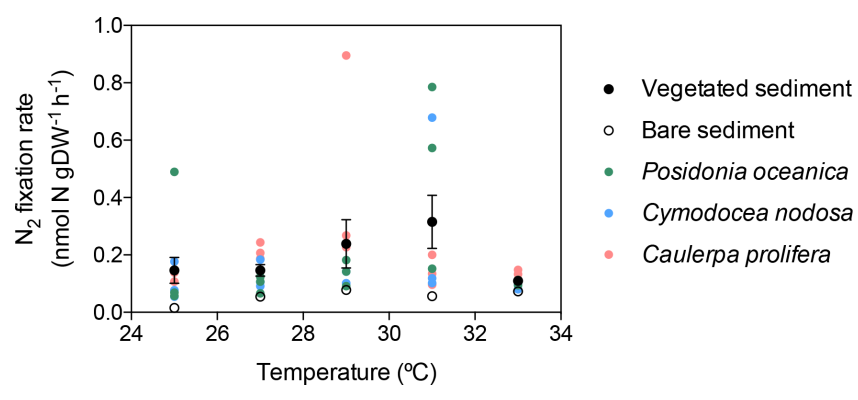

Figure 2. Relationship of experimental incubation temperature and mean sediment $\mathrm{N}_{2}$ fixation rates (expressed by sediment dry weight) in vegetated (black dots) and bare sediments (open dots). Black and open dots indicate mean values, and errors bars indicate standard error of the mean. Individual replicate measurements of $\mathrm{N}_{2}$ fixation rates for each macrophyte species are also shown in colored-coded dots; green dots represent measurements on $P$. oceanica sediments, blue dots represent measurements on $C$. nodosa sediments, and pink dots represent measurements on C. prolifera sediments.

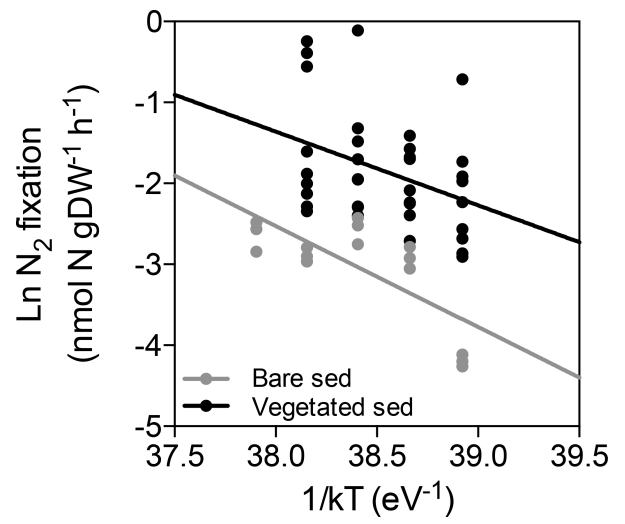

Figure 3. Arrhenius plot for $\mathrm{N}_{2}$ fixation rates in vegetated (black dots) and bare sediments (grey dots), showing the linear regression between $\ln \mathrm{N}_{2}$ fixation rates and the inverse of the temperature multiplied by the Boltzmann constant (1/kT) for vegetated (black solid line) and bare (grey solid line) sediments.

ries might slightly overestimate rates due to sediment structure disturbance and increases in organic matter availability, incubation chambers might underestimate rates due to poor diffusion of acetylene into the sediment (Welsh, 2000). Nevertheless, the $\mathrm{N}_{2}$ fixation rates in bare sediments at current summer mean SST $\left(1.14 \pm 0.31 \mathrm{mg} \mathrm{N} \mathrm{m}^{-2} \mathrm{~d}^{-1}\right)$ are very similar to those measured by benthic bell-jar in bare sediment adjacent to a $P$. oceanica meadow (from 0.01 to $1.99 \mathrm{mg}$ $\mathrm{N} \mathrm{m}^{-2} \mathrm{~d}^{-1}$ ) (Agawin et al., 2017), suggesting that these differences in $\mathrm{N}_{2}$ fixation rates in $P$. oceanica sediment might also be due to variability among sites. The $\mathrm{N}_{2}$ fixation rates in C. nodosa and C. prolifera sediments reported here are the first reports, to the best of our knowledge, for these two important Mediterranean macrophyte species. Indeed, the analysis of sediment $\mathrm{N}$ stocks in a $C$. nodosa meadow in the
Mediterranean Sea suggested that $\mathrm{N}_{2}$ fixation might be contributing to enhancing the $\mathrm{N}$ stocks compared to bare sediments (Pedersen et al., 1997). The similar stable $\mathrm{N}$ isotope composition of $C$. nodosa tissues and those of $P$. oceanica in the Mediterranean (Fourqurean et al., 2007) also suggests that they use similar sources of nitrogen. The $\mathrm{N}_{2}$ fixation rates at current summer mean SST in $C$. prolifera sediments found here $\left(0.17 \pm 0.04 \mathrm{nmol} \mathrm{Ng} \mathrm{DW}^{-1} \mathrm{~h}^{-1}\right)$ are similar to the sediment $\mathrm{N}_{2}$ fixation rates associated with the invasive C. taxifolia in Monaco $\left(0.12 \pm 0.09 \mathrm{nmol} \mathrm{N} \mathrm{g} \mathrm{DW}^{-1} \mathrm{~h}^{-1}\right)$ but 20 -fold lower than the $\mathrm{N}_{2}$ fixation rates reported for $C$. taxifolia in France $\left(3.96 \pm 1.99 \mathrm{nmol} \mathrm{N} \mathrm{g} \mathrm{DW}^{-1} \mathrm{~h}^{-1}\right.$ ) (Chisholm and Moulin, 2003).

Although the sediments colonized by these three macrophyte species hold similar rates, the contribution of sediment $\mathrm{N}_{2}$ fixation to the productivity of each plant is different. Taking into account the average net production (2.63 and $1.47 \mathrm{~g} \mathrm{DW} \mathrm{m}^{-2} \mathrm{~d}^{-1}$ for $P$. oceanica and $C$. nodosa, respectively (Duarte and Chiscano, 1999), and $5.16 \mathrm{~g} \mathrm{DW} \mathrm{m}^{-2} \mathrm{~d}^{-1}$ for $C$. prolifera, Marbà, unpublished) and the tissue nitrogen content (from $1.55 \%$ to $1.63 \%$ for P. oceanica, from $1.91 \%$ to $2.28 \%$ for $C$. nodosa (Duarte, 1990; Fourqurean et al., 2007), and from $3 \%$ to $4.9 \%$ for $C$. prolifera; Morris et al., 2009), the mean measured sediment $\mathrm{N}_{2}$ fixation rates detected at current summer mean SST $\left(25\right.$ and $\left.27^{\circ} \mathrm{C}\right)$ could account for $6.7 \%$ to $7 \%, 11.5 \%$ to $13.8 \%$, and $1.1 \%$ to $1.8 \%$ of the nitrogen requirements for $P$. oceanica, C. nodosa, and $C$. prolifera, respectively. The calculated contribution of $\mathrm{N}_{2}$ fixation to seagrass growth requirements falls within the range of the $\mathrm{N}_{2}$ fixation contributions reported for temperate seagrasses, ranging from $5 \%$ to $12 \%$ for $Z$. marina and Z. noltii, respectively (Welsh, 2000). The calculated contribution of $\mathrm{N}_{2}$ fixation to fulfilling the macrophyte growth requirements points to $\mathrm{N}_{2}$ fixation as partially supporting the high productivity of these primary producers in Mediterranean oligotrophic waters.

We experimentally demonstrate that $\mathrm{N}_{2}$ fixation in coastal sediments is thermal dependent, both in vegetated and bare sediments. Despite the fact that a formal experimental demonstration was lacking, the $\mathrm{N}_{2}$ fixation thermal dependence reported here is in agreement with the higher rates typically measured in warm tropical and subtropical meadows compared to the rates reported in temperate and cold seagrass systems (Herbert, 1999; McGlathery, 2008; Welsh, 2000). The thermal dependence, as reflected by the activation energy and $Q_{10}$, for $\mathrm{N}_{2}$ fixation rates was, however, higher in bare sediments than in vegetated sediments, possibly due to different bacterial communities. Westrich and Berner (1988) also found that sulfate reduction exhibited a more pronounced thermal dependence in sediments supporting lower rates. The activation energies for $\mathrm{N}_{2}$ fixation in vegetated sediments $(0.91 \pm 0.4 \mathrm{eV}$ or $\left.87.8 \pm 37.6 \mathrm{KJ} \mathrm{mol}^{-1}\right)$ and in bare sediments $(1.25 \pm 0.4 \mathrm{eV}$ or $120.6 \pm 37.6 \mathrm{KJ} \mathrm{mol}^{-1}$ ) are within the range of the activation energy reported for sediment sulfate reduction (range 
from 36 to $132 \mathrm{KJ} \mathrm{mol}^{-1}$; Robador et al., 2016; Westrich and Berner, 1988) and for sediment organic matter degradation (range from 54 to $125 \mathrm{KJ} \mathrm{mol}^{-1}$; Middelburg et al., 1996). The $Q_{10}$ values associated with sediment $\mathrm{N}_{2}$ fixation (3.84 \pm 2.22 and $6.41 \pm 2.97$ for vegetated and bare sediments, respectively) are higher than those reported for sediment sulfate reduction (from 1.6 to 3.4; Robador et al., 2016), but still similar to values associated with organic matter degradation (from 2.2 to 6.3; Middelburg et al., 1996). Moreover, the thermal response differed for vegetated sediments, in which $\mathrm{N}_{2}$ fixation rates showed an optimum at $31^{\circ} \mathrm{C}$, followed by a sharp decrease at $33^{\circ} \mathrm{C}$, and bare sediments, in which $\mathrm{N}_{2}$ fixation rates increased along the range of experimental temperatures tested here. The thermal response of $\mathrm{N}_{2}$ fixation in vegetated sediments found here is similar to the thermal response reported for $\mathrm{N}_{2}$ fixation in soil crusts (Zhou et al., 2016) and seagrass rhizosphere (Garcias-Bonet et al., 2018), with an increase in rates up to 30 and $29^{\circ} \mathrm{C}$, respectively, and a marked decrease in rates at temperatures above the optimum. The forecasted warming by the end of the century could potentially increase $\mathrm{N}_{2}$ fixation rates by $36.7 \%$ in vegetated sediments and $46.8 \%$ in bare sediments. However, the decrease in $\mathrm{N}_{2}$ fixation rates in vegetated sediments at $33^{\circ} \mathrm{C}$ would imply a reduction of a third in the contribution of $\mathrm{N}_{2}$ fixation to the macrophyte productivity during heat waves. The forecasted warming could also affect other biogeochemical processes in coastal sediments, such as sulfate reduction (Robador et al., 2016), anaerobic ammonium oxidation, and denitrification (Garcias-Bonet et al., 2018; Nowicki, 1994), among others, and therefore potential synergic or antagonistic effects may occur. Responses of sediments colonized by different macrophyte species may also differ due to differences in the lability of their OM and nutrient stocks associated with differences in $\mathrm{C}: \mathrm{N}: \mathrm{P}$ ratios (Enríquez et al., 1993; Lanari et al., 2018). Similarly, losses of seagrass coverage by heat waves could lead to an increase in $\mathrm{CO}_{2}$ emissions by increased remineralization of $\mathrm{C}$ stocks (Arias-Ortiz et al., 2018).

The thermal dependence of $\mathrm{N}_{2}$ fixation in vegetated sediments found here might have important consequences for primary production in coastal ecosystems in the context of warming. This may not be the case for $P$. oceanica, as this species is projected to be critically compromised to the extent that functional extinction is possible, with projected Mediterranean warming rates by 2050-2100 (Chefaoui et al., 2018; Jordà et al., 2012). However, in order to draw general conclusions on the effect of warming on $\mathrm{N}_{2}$ fixation in coastal ecosystems, the thermal dependence found here needs be tested for a diversity of seagrass ecosystems. Similarly, our results from experimental temperature treatments did not account for potential acclimation and adaptation of microbial communities to warming, which should also be tested. Moreover, $\mathrm{N}_{2}$ fixation is likely to be subjected to other environmental controls that may change, either in an additive, synergistic, or antagonistic manner, with warming, so predicting
$\mathrm{N}_{2}$ fixation rates in a future warmer coastal ocean remains challenging.

\section{Conclusions}

Mediterranean macrophyte meadows are sites of intense $\mathrm{N}_{2}$ fixation rates twice as high as those in adjacent bare sediments. As these rates increase with warming, actual warming of the Mediterranean Sea is expected to lead to enhanced sediment $\mathrm{N}_{2}$ fixation rates, with future warming leading to further increases in $\mathrm{N}_{2}$ fixation rates up to $33^{\circ} \mathrm{C}$ in bare sediments and $31^{\circ} \mathrm{C}$, followed by a decrease at higher temperatures in vegetated sediments. However, more work covering a larger area is needed to confirm a generalized warming effect on sediment $\mathrm{N}_{2}$ fixation.

Data availability. The dataset is provided in the attached Supplement (Table S3).

Supplement. The supplement related to this article is available online at: https://doi.org/10.5194/bg-16-167-2019-supplement.

Author contributions. NGB, RVS, CMD, and NM designed the study. NGB and RVS performed the fieldwork and sample and data analysis. NGB, RVS, CMD, and NM interpreted the results. NGB wrote the first draft of the paper. All authors contributed substantially to the final paper.

Competing interests. The authors declare that they have no conflict of interest.

Acknowledgements. This work was funded by the Spanish Ministry of Economy, Industry and Competitiveness (Medshift project, CGL2015-71809-P) with baseline funding allocated by the King Abdullah University of Science and Technology to CMD. We thank Carlos Alex Morell Lujan Williams for field assistance and Maria Trinidad García Barceló for lab support. RVS was supported by a Juan de la Cierva incorporación contract (ref. IJCI-2015-23163).

Edited by: Clare Woulds

Reviewed by: Carmen B. de los Santos and one anonymous referee

\section{References}

Agawin, N. S., Ferriol, P., Sintes, E., and Moyà, G.: Temporal and spatial variability of in situ nitrogen fixation activities associated with the Mediterranean seagrass Posidonia oceanica meadows, Limnol. Oceanogr., 62, 2575-2592, 2017.

Agawin, N. S. R., Ferriol, P., Cryer, C., Alcon, E., Busquets, A., Sintes, E., Vidal, C., and Moyà, G.: Significant nitrogen fixation 
activity associated with the phyllosphere of Mediterranean seagrass Posidonia oceanica: first report, Mar. Ecol. Prog. Ser., 551, 53-62, 2016.

Arias-Ortiz, A., Serrano, O., Masqué, P., Lavery, P. S., Mueller, U., Kendrick, G. A., Rozaimi, M., Esteban, A., Fourqurean, J. W., and Marbà, N.: A marine heatwave drives massive losses from the world's largest seagrass carbon stocks, Nat. Clim. Change, 8 , 338-344, 2018.

Belkin, I. M.: Rapid warming of large marine ecosystems, Prog. Oceanogr., 81, 207-213, 2009.

Béthoux, J. P. and Copin-Montégut, G.: Biological Fixation of Atmospheric Nitrogen in the Mediterranean-Sea, Limnol. Oceanogr., 31, 1353-1358, 1986.

Breitbarth, E., Mills, M. M., Friedrichs, G., and LaRoche, J.: The Bunsen gas solubility coefficient of ethylene as a function of temperature and salinity and its importance for nitrogen fixation assays, Limnol. Oceanogr.-Method., 2, 282-288, 2004.

Burrows, M. T., Schoeman, D. S., Buckley, L. B., Moore, P., Poloczanska, E. S., Brander, K. M., Brown, C., Bruno, J. F., Duarte, C. M., and Halpern, B. S.: The pace of shifting climate in marine and terrestrial ecosystems, Science, 334, 652-655, 2011.

Calleja, M., Marba, N., and Duarte, C. M.: The relationship between seagrass (Posidonia oceanica) decline and porewater sulfide pools in carbonate sediments, Estua. Coast. Shelf Sci., 73, 583-588, 2007.

Capone, D. G. and Taylor, B. F.: $\mathrm{N}_{2}$ fixation in the rhizosphere of Thalassia-Testudinum, Can. J. Microbiol., 26, 998-1005, 1980.

Capone, D. G.: Nitrogen-Fixation (Acetylene-Reduction) by Rhizosphere Sediments of the Eelgrass Zostera-Marina, Mar. Ecol.Prog. Ser., 10, 67-75, 1982.

Capone, D. G.: Benthic nitrogen fixation, in: Nitrogen cycling in coastal marine environments, edited by: Blackburn, T. H. and Sørensen, J., John Wiley \& Sons, New York, 85-123, 1988.

Chefaoui, R. M., Assis, J., Duarte, C. M., and Serrão, E. A.: Large-scale prediction of seagrass distribution integrating landscape metrics and environmental factors: the case of Cymodocea nodosa (Mediterranean-Atlantic), Estuar. Coast., 39, 123-137, 2016.

Chefaoui, R. M., Duarte, C. M., and Serrão, E. A.: Dramatic loss of seagrass habitat under projected climate change in the Mediterranean Sea, Glob. Change Biol., 24, 4919-4928, 2018.

Chisholm, J. R. and Moulin, P.: Stimulation of nitrogen fixation in refractory organic sediments by Caulerpa taxifolia (Chlorophyta), Limnol. Oceanogr., 48, 787-794, 2003.

Costanza, R., d'Arge, R., De Groot, R., Farber, S., Grasso, M., Hannon, B., Limburg, K., Naeem, S., O'neill, R. V., and Paruelo, J.: The value of the world's ecosystem services and natural capital, Nature, 387, 253-260, 1997.

Dean Jr., W. E.: Determination of carbonate and organic matter in calcareous sediments and sedimentary rocks by loss on ignition: comparison with other methods, J. Sediment. Res., 44, 242-248, 1974.

Dell, A. I., Pawar, S., and Savage, V. M.: Systematic variation in the temperature dependence of physiological and ecological traits, $\mathrm{P}$. Natl. Acad. Sci. USA, 108, 10591-10596, 2011.

Diffenbaugh, N. S., Pal, J. S., Giorgi, F., and Gao, X.: Heat stress intensification in the Mediterranean climate change hotspot, Geophys. Res. Lett., 34, 2007.
Duarte, B., Martins, I., Rosa, R., Matos, A. R., Roleda, M. Y., Reusch, T., Engelen, A. H., Serrao, E. A., Pearson, G. A., and Marques, J. C. J.: Climate change impacts on seagrass meadows and macroalgal forests: an integrative perspective on acclimation and adaptation potential, Front. Mar. Sci., 5, 190, 2018.

Duarte, C. M.: Seagrass nutrient content, Mar. Ecol. Prog. Ser., 6, 201-207, 1990.

Duarte, C. M.: Reviews and syntheses: Hidden forests, the role of vegetated coastal habitats in the ocean carbon budget, Biogeosciences, 14, 301-310, https://doi.org/10.5194/bg-14-301-2017, 2017.

Duarte, C. M. and Chiscano, C. L.: Seagrass biomass and production: a reassessment, Aquat. Bot., 65, 159-174, 1999.

Enríquez, S., Duarte, C. M., and Sand-Jensen, K.: Patterns in decomposition rates among photosynthetic organisms: the importance of detritus $\mathrm{C}: \mathrm{N}: \mathrm{P}$ content, Oecologia, 94, 457-471, 1993.

Fourqurean, J. W., Marbà, N., Duarte, C. M., Diaz-Almela, E., and Ruiz-Halpern, S.: Spatial and temporal variation in the elemental and stable isotopic content of the seagrasses Posidonia oceanica and Cymodocea nodosa from the Illes Balears, Spain, Mar. Biol., 151, 219-232, https://doi.org/10.1007/s00227-006-04733, 2007.

Fourqurean, J. W., Duarte, C. M., Kennedy, H., Marbà, N., Holmer, M., Mateo, M. A., Apostolaki, E. T., Kendrick, G. A., KrauseJensen, D., and McGlathery, K. J.: Seagrass ecosystems as a globally significant carbon stock, Nat. Geosci., 5, 505-509, 2012.

García, R., Holmer, M., Duarte, C. M., and Marbà, N.: Global warming enhances sulphide stress in a key seagrass species (NW Mediterranean), Glob. Change Biol., 19, 3629-3639, 2013.

Garcias-Bonet, N., Marba, N., Holmer, M., and Duarte, C. M.: Effects of sediment sulfides on seagrass Posidonia oceanica meristematic activity, Mar. Ecol.-Prog. Ser., 372, 1-6, 2008.

Garcias-Bonet, N., Arrieta, J. M., de Santana, C. N., Duarte, C. M., and Marbà, N.: Endophytic bacterial community of a Mediterranean marine angiosperm (Posidonia oceanica), Front. Microbiol., 3, 342, https://doi.org/10.3389/fmicb.2012.00342, 2012.

Garcias-Bonet, N., Arrieta, J. M., Duarte, C. M., and Marba, N.: Nitrogen-fixing bacteria in Mediterranean seagrass (Posidonia oceanica) roots, Aquat. Bot., 131, 57-60, https://doi.org/10.1016/j.aquabot.2016.03.002, 2016.

Garcias-Bonet, N., Fusi, M., Ali, M., Shaw, D. R., Saikaly, P. E., Daffonchio, D., and Duarte, C. M.: High denitrification and anaerobic ammonium oxidation contributes to net nitrogen loss in a seagrass ecosystem in the central Red Sea, Biogeosciences, 15, 7333-7346, https://doi.org/10.5194/bg-15-7333-2018, 2018.

Herbert, R. A.: Nitrogen cycling in coastal marine ecosystems, Fems Microbiol. Rev., 23, 563-590, 1999.

IPCC: Climate change 2013: The physical science basis. Contribution of Working Group I to the Fifth Assessment Report (AR5) of the Intergovernmental Panel on Climate Change Cambridge Univ Press, New York, USA, 2013.

Jordà, G., Marbà, N., and Duarte, C. M.: Mediterranean seagrass vulnerable to regional climate warming, Nat. Clim. Change, 2, 821-824, 2012.

Koch, M. S., Schopmeyer, S., Kyhn-Hansen, C., and Madden, C. J.: Synergistic effects of high temperature and sulfide on tropical seagrass, J. Exp. Mar. Biol. Ecol., 341, 91-101, https://doi.org/10.1016/j.jembe.2006.10.004, 2007. 
Lanari, M., Claudino, M. C., Garcia, A. M., and da Silva Copertino, M.: Changes in the elemental $(\mathrm{C}, \mathrm{N})$ and isotopic $\left(\delta^{13} \mathrm{C}, \delta^{15} \mathrm{~N}\right)$ composition of estuarine plants during diagenesis and implications for ecological studies, J. Exp. Mar. Biol. Ecol., 500, 46-54, 2018.

Lehnen, N., Marchant, H. K., Schwedt, A., Milucka, J., Lott, C., Weber, M., Dekaezemacker, J., Seah, B. K. B., Hach, P. F., Mohr, W., and Kuypers, M. M. M.: High rates of microbial dinitrogen fixation and sulfate reduction associated with the Mediterranean seagrass Posidonia oceanica, Syst. Appl. Microbiol., 39, 476483, https://doi.org/10.1016/j.syapm.2016.08.004, 2016.

Lloret, J., Marín, A., and Marín-Guirao, L.: Is coastal lagoon eutrophication likely to be aggravated by global climate change?, Estuar. Coast. Shelf Sci., 78, 403-412, 2008.

Marba, N. and Duarte, C. M.: Mediterranean warming triggers seagrass (Posidonia oceanica) shoot mortality, Glob. Change Biol., 16, 2366-2375, 2010.

Marbà, N., Jordà, G., Agustí, S., Girard, C., and Duarte, C. M.: Footprints of climate change on Mediterranean Sea biota, Front. Mar. Sci., 2, 56, 2015.

McGlathery, K. J., Risgaard-Petersen, N., and Christensen, P. B.: Temporal and spatial variation in nitrogen fixation activity in the eelgrass Zostera marina rhizosphere, Mar. Ecol.-Prog. Ser., 168, 245-258, 1998.

McGlathery, K. J.: Seagrass habitats, in: Nitrogen in the Marine Environment, 2nd edn., edited by: Capone, D. G., Bronk, D. A., Mulholland, M. R., and Carpenter, E. J., Elsevier Academic Press Inc, 525 B Street, Suite 1900, San Diego, Ca 92101-4495 USA, 2008.

Middelburg, J. J., Klaver, G., Nieuwenhuize, J., Wielemaker, A., de Hass, W., Vlug, T., and van der Nat, J. F.: Organic matter mineralization in intertidal sediments along an estuarine gradient, Mar. Ecol. Prog. Ser., 132, 157-168, 1996.

Morris, E. P., Peralta, G., Benavente, J., Freitas, R., Rodrigues, A. M., Quintino, V., Alvarez, O., Valcárcel-Pérez, N., Vergara, J. J., and Hernández, I.: Caulerpa prolifera stable isotope ratios reveal anthropogenic nutrients within a tidal lagoon, Mar. Ecol. Prog. Ser., 390, 117-128, 2009.

Nowicki, B. L.: The effect of temperature, oxygen, salinity, and nutrient enrichment on estuarine denitrification rates measured with a modified nitrogen gas flux technique, Estuar. Coast. Shelf Sci., 38, 137-156, 1994.

Oliver, E. C., Donat, M. G., Burrows, M. T., Moore, P. J., Smale, D. A., Alexander, L. V., Benthuysen, J. A., Feng, M., Gupta, A. S., and Hobday, A. J.: Longer and more frequent marine heatwaves over the past century, Nat. Commun., 9, 1324, https://doi.org/10.1038/s41467-018-03732-9, 2018.

Olsen, Y. S., Sánchez-Camacho, M., Marbà, N., and Duarte, C. M.: Mediterranean seagrass growth and demography responses to experimental warming, Estuar. Coast., 35, 1205-1213, 2012.
Pedersen, M. F., Duarte, C. M., and Cebrián, J.: Rates of changes in organic matter and nutrient stocks during seagrass Cymodocea nodosa colonization and stand development, Mar. Ecol. Prog. Ser., 159, 29-36, 1997.

Perkins, S., Alexander, L., and Nairn, J.: Increasing frequency, intensity and duration of observed global heatwaves and warm spells, Geophys. Res. Lett., 39, 2012.

Raven, J. A. and Geider, R. J.: Temperature and algal growth, New Phytol., 110, 441-461, 1988.

Robador, A., Müller, A. L., Sawicka, J. E., Berry, D., Hubert, C. R. J., Loy, A., Jørgensen, B. B., and Brüchert, V.: Activity and community structures of sulfate-reducing microorganisms in polar, temperate and tropical marine sediments, Isme J., 10, 796-809, https://doi.org/10.1038/ismej.2015.157, 2016.

Sanz-Lázaro, C., Valdemarsen, T., Marín, A., and Holmer, M.: Effect of temperature on biogeochemistry of marine organicenriched systems: implications in a global warming scenario, Ecol. Appl., 21, 2664-2677, 2011.

Vaquer-Sunyer, R. and Duarte, C. M.: Experimental evaluation of the response of coastal Mediterranean planktonic and benthic metabolism to warming, Estuar. Coast., 36, 697-707, 2013.

Vaquer-Sunyer, R., Duarte, C. M., Jordà, G., and Ruiz-Halpern, S.: Temperature dependence of oxygen dynamics and community metabolism in a shallow Mediterranean macroalgal meadow (Caulerpa prolifera), Estuar. Coast., 35, 1182-1192, 2012.

Vargas-Yáñez, M., García, M. J., Salat, J., García-Martínez, M., Pascual, J., and Moya, F.: Warming trends and decadal variability in the Western Mediterranean shelf, Global Planet. Change, 63, 177-184, 2008.

Welsh, D. T., Bourgues, S., de Wit, R., and Herbert, R. A.: Seasonal variations in nitrogen-fixation (acetylene reduction) and sulphate-reduction rates in the rhizosphere of Zostera noltii: Nitrogen fixation by sulphate reducing bacteria, Mar. Biol., 125, 619-628, 1996.

Welsh, D. T.: Nitrogen fixation in seagrass meadows: Regulation, plant-bacteria interactions and significance to primary productivity, Ecol. Lett., 3, 58-71, 2000.

Westrich, J. T. and Berner, R. A.: The effect of temperature on rates of sulfate reduction in marine sediments, Geomicrobiol. J., 6, 99117, 1988.

Wilson, S. T., Böttjer, D., Church, M. J., and Karl, D. M.: Comparative Assessment of Nitrogen Fixation Methodologies, Conducted in the Oligotrophic North Pacific Ocean, Appl. Environ. Microbiol., 78, 6516-6523, https://doi.org/10.1128/aem.0114612, 2012.

Zhou, X., Smith, H., Silva, A. G., Belnap, J., and GarciaPichel, F.: Differential responses of dinitrogen fixation, diazotrophic cyanobacteria and ammonia oxidation reveal a potential warming-induced imbalance of the $\mathrm{N}$ cycle in biological soil crusts, PloS one, 11, e0164932, https://doi.org/10.1371/journal.pone.0164932, 2016. 